\title{
PATIENT SATISFACTION OF HEALTH SERVICES PROVIDED AFTER ISO 9OO1 IMPLEMENTATION AT COMMUNITY HEALTH CENTERS IN YOGYAKARTA
}

\author{
Jati Untari, Marianus Ikeputra Usman \\ Department of Public Health, Respati University, Yogyakarta
}

\begin{abstract}
Background: ISO 9001 sets out the criteria for a quality management system and is the only standard in the family that can be certified to. This standard is based on a number of quality management principles including a strong customer focus, the motivation and implication of top management, the process approach and continual improvement. It can be used by any organization, large or small, regardless of its field of activity. Some community health centers in Yogyakarta have implemented ISO 9001 with an objective to improve quality of health services provided and patient satisfaction. This study aimed to determine difference in patient satisfaction between community health center with ISO 9001 and community health center without ISO 9001.

Subjects and Method: This was an analytic cross sectional study conducted in community health centers with and without ISO 9001 certification in Yogyakarta. A sample of 174 patients was selected for this study consisting of 87 patients from community health center Umbulharjo I with ISO 9001 and 87 patients from community health center Umbulharjo II without ISO 9001. Patients satisfaction was measured based on Servequal with 5 dimensions of quality: reliability, tangible, responsiveness, assurance, and empathy. Difference in percent satisfaction between the 2 groups was tested by chi square.
\end{abstract}

Results: Patient satisfaction in health center with ISO 9001 certification (85.6\%) was higher than that in health center without ISO 9001 certification $(79.5 \%)$, and it was statistically significant $(\mathrm{p}=0.002)$.

Conclusion: ISO 9001 certification improves quality of health service provided at community health centers.

Keywords: patient satisfaction, health centers, ISO, NON-ISO

Correspondence: Jati Untari. Department of Public Health, Respati University, Yogyakarta. Email: jatiuntari@gmail.com 